\title{
Review
}

\section{How to Select Firefly Luciferin Analogues for In Vivo Imaging}

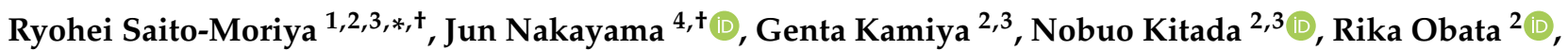 \\ Shojiro A. Maki ${ }^{2,3}$ and Hiroshi Aoyama ${ }^{1}$
}

1 School of Pharmacy, Tokyo University of Pharmacy and Life Sciences, Tokyo 192-0392, Japan; aoyamahr@toyaku.ac.jp

2 Department of Engineering Science, Graduate School of Informatics and Engineering, The University of Electro-Communications, Tokyo 182-8585, Japan; kamiya0801@uec.ac.jp (G.K.); kitada@uec.ac.jp (N.K.); robatad@uec.ac.jp (R.O.); s-maki@uec.ac.jp (S.A.M.)

3 Center for Neuroscience and Biomedical Engineering, The University of Electro-Communications, Tokyo 182-8585, Japan

4 Division of Cellular Signaling, National Cancer Center Research Institute, Tokyo 104-0045, Japan; jnakayama.re@gmail.com

* Correspondence: rsaito@toyaku.ac.jp; Tel.: +81-42-676-3251; Fax: +81-42-676-3243

+ These authors contributed equally to this work.

Citation: Saito-Moriya, R.;

Nakayama, J.; Kamiya, G.; Kitada, N.; Obata, R.; Maki, S.A.; Aoyama, H. How to Select Firefly Luciferin Analogues for In Vivo Imaging. Int. J. Mol. Sci. 2021, 22, 1848. https:// doi.org/10.3390/ijms22041848

Academic Editor: Eugene S. Vysotski

Received: 22 January 2021

Accepted: 9 February 2021

Published: 12 February 2021

Publisher's Note: MDPI stays neutral with regard to jurisdictional claims in published maps and institutional affiliations.

Copyright: (c) 2021 by the authors. Licensee MDPI, Basel, Switzerland. This article is an open access article distributed under the terms and conditions of the Creative Commons Attribution (CC BY) license (https:// creativecommons.org/licenses/by/ $4.0 /)$.

\begin{abstract}
Bioluminescence reactions are widely applied in optical in vivo imaging in the life science and medical fields. Such reactions produce light upon the oxidation of a luciferin (substrate) catalyzed by a luciferase (enzyme), and this bioluminescence enables the quantification of tumor cells and gene expression in animal models. Many researchers have developed single-color or multicolor bioluminescence systems based on artificial luciferin analogues and/or luciferase mutants, for application in vivo bioluminescence imaging (BLI). In the current review, we focus on the characteristics of firefly BLI technology and discuss the development of luciferin analogues for high-resolution in vivo BLI. In addition, we discuss the novel luciferin analogues TokeOni and seMpai, which show potential as high-sensitivity in vivo BLI reagents.
\end{abstract}

Keywords: bioluminescence imaging; near-infrared light; luciferin analogue; luciferase; multicolor; high sensitivity

\section{Introduction}

There are many bioluminescent organisms [1-3], such as the firefly and the luminous shrimp. These organisms produce light by bioluminescence reactions involving the oxidation of a luciferin (substrate) catalyzed by a luciferase (enzyme) (Table 1). For instance, firefly bioluminescence originates from the oxidation of D-luciferin (DLH2) catalyzed by firefly luciferase (Fluc) in the presence of adenosine triphosphate (ATP), $\mathrm{Mg}^{2+}$ and $\mathrm{O}_{2}$. This reaction proceeds by two-steps: DLH2 is first adenylated with ATP, and then it is oxidized by $\mathrm{O}_{2}$, to generate excited oxyluciferin, which produces yellow-green light $\left(\lambda_{\max }=560 \mathrm{~nm}\right)$ [4-7]. In contrast, bioluminescence in the luminous shrimp, one of many bioluminescent marine species, is generated by the oxidation of coelenterazine (CTZ) catalyzed by oplophorus luciferase (Oluc) in the presence of $\mathrm{O}_{2}$ to generate coelenteramide, which produces blue light $\left(\lambda_{\max }=454 \mathrm{~nm}\right)$ [8-10].

Recently, Oba et al. published a report on the evolutionary history of firefly bioluminescence [11]. They recreated putative ancestral firefly luciferases by predicting their amino acid sequences with a maximum-likelihood method of ancestral state reconstruction [12] and experimentally characterized their enzymatic properties, including their luminescence colors. The firefly family evolved from Lampyridae-Phengodidae-Rhagophthalmidae lineage, which produces a weak and red light, with the first firefly that appeared producing deep-green light. Thereafter, fireflies with different luminescent colors appeared gradually, as the species underwent divergent evolution. These results suggest to be extremely useful 
information in the case of improving luciferase mutants for changing bioluminescence colors in the future.

Table 1. Details of typical natural substrates and co-factors for bioluminescence reactions.

\begin{tabular}{ccc}
\hline Luciferase & Species & Co-Factors \\
\hline References
\end{tabular}

Firefly luciferin- and luciferase-based bioluminescence imaging (BLI) is widely utilized in the life science and medical science fields $[13,14]$, for in vitro and in vivo study of the central nervous system (CNS) [15], fungal pathogens [16,17], immunity [18], microglia [19], neuroinflammation [20], parasites [21], stem cells [22], transporters [23], and viruses [24-26], among others. For example, in vitro luciferase assays are widely used for the quantification of gene promoter activities [27]. Luciferin-luciferase reactions are also used for in vivo realtime monitoring of gene expression, cell numbers, and other biological events. Specifically, firefly BLI has been utilized for in vivo study in numerous mouse models [28-36]. For instance, it has been used to quantify tumor cells [37] and monitor gene expression in transgenic mouse models [38]. Now many researchers use the improved luciferase genes for the experiment in life science (e.g., luct, luc2). The $l u c 2$ gene, which is developed by adjustment of codon and reducing of the transcription factor binding site from wild-type luciferase sequence, enables the high expression of luciferase in mammalian cells [39].

On the other hand, many researchers have synthesized CTZ analogues for application to optical imaging [40-48]. For instance, Hall et al. developed an artificial bioluminescence pair, the substrate furimazine (FMZ) and the mutant luciferase NanoLuc ${ }^{\circledR}$ [49-51]. Since the FMZ/NanoLuc ${ }^{\circledR}$ reaction is independent of the concentration of ATP [52], it is a useful tool for studying exosomes, blood, and urine, where ATP abundance is limited [53]. This is particularly important because the native firefly bioluminescence reaction is not suitable for monitoring exosomes [54], as it is ATP-dependent. However, generally, CTZ and derivatives are proceeded by auto-oxidation, in the absence of luciferase, resulting high background signals are detected in cell or animal experiments [55]. In contrast, DLH2 has some advantages, such as low background signals, excellent bioavailability, and easy handling [56].

Firefly BLI methods are based on the detection of optical signals and are, thus, more suitable for imaging shallow tissues, such as subcutaneous tissue, than for imaging deeper tissues, such as those in the brain or lungs $[57,58]$. This is because deep-tissue imaging is difficult by the poor light permeability of biological tissue. Yellow-green light, produced by natural firefly bioluminescence (DLH2/Fluc), is absorbed and scattered by bio-tissue [59,60]. Therefore, BLI of DLH2/Fluc suffered from weak luminescence intensity and short emission wavelengths $(560 \mathrm{~nm})$. Another reason is the poor biodistribution of DLH2 [61]. For example, a study using ${ }^{14} \mathrm{C}$ labeled DLH2 revealed that, after $15 \mathrm{~min}$ of intraperitoneal administration, DLH2 is distributed mainly at the skin and does not reach the brain or lungs [62].

Accordingly, numerous luciferin analogues [63,64] and mutant luciferases [65-70] have been developed for high-resolution detection. A particularly important development in in vivo BLI technology is the development of luciferin analogues and mutant luciferases 
that provide near-infrared (NIR) wavelength luminescence. This is because NIR imaging makes it possible to efficiently image deep tissue even at lower luminescence intensity.

Since different luciferin analogues and luciferase mutants have their own strengths and weaknesses, it is important to choose the right combination for a particular in vitro and in vivo experiment. Most previous research has used single-color in vivo BLI. However, multicolor bioluminescence reactions have been developed for application to in vivo imaging.

In this review, we present a brief introduction to the characteristics of firefly BLI technology and discuss advances in the development of luciferin analogues and luciferase mutants for high-resolution in vivo BLI.

\section{The Development of Luciferin and Luciferase for NIR BLI}

\subsection{Luciferin Analogues that Produce NIR Light}

Luciferin analogues have been synthesized as a means to overcome the two weaknesses of DLH2 mentioned above, i.e., low light permeability and biodistribution, thus realizing higher sensitivity and utility for in vivo imaging (Table 2). A viable strategy here is to change the luminescence color of DLH2 from yellow-green to NIR light. Since NIR light permeates biological tissues well, NIR luminescence is suitable for detecting signals from deep tissue, such as the brain and lungs [59]. Another strategy is the synthesis of luciferin analogues with increased hydrophobicity for improved cell membrane permeability [71]. These two approaches have resulted in luciferin analogues with improved characteristics for in vivo imaging, as discussed below.

Table 2. Application of firefly bioluminescence reactions to imaging.

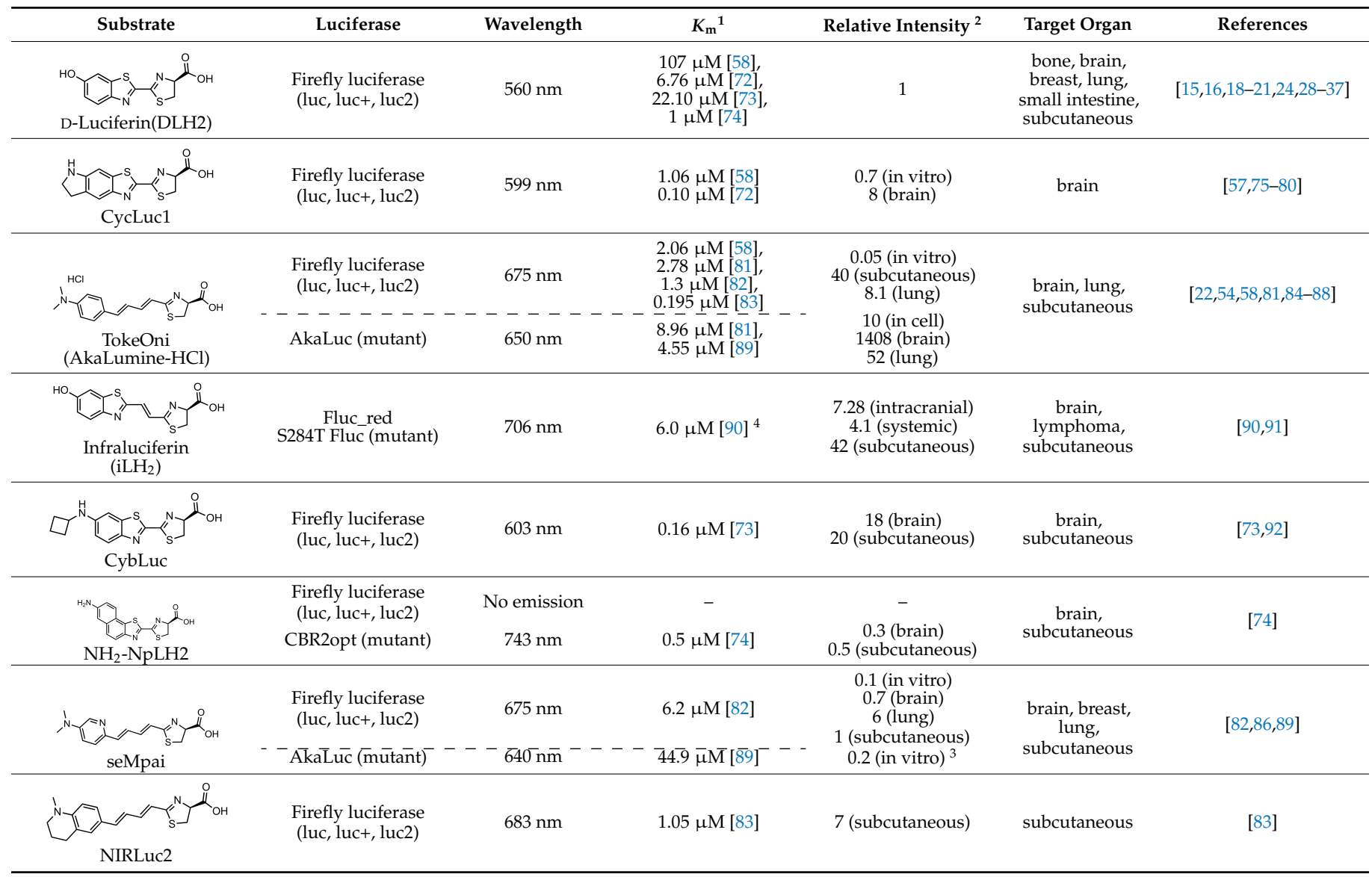

${ }^{1}$ The detailed conditions are various and confirm if need. ${ }^{2}$ Relative light intensity compared to DLH2. ${ }^{3}$ Relative light intensity compared to TokeOni/AkaLuc. ${ }^{4}$ The $K_{\mathrm{m}}$ value with $\mathrm{x} 5$ Fluc, which is a thermostable Fluc mutant. 
Miller et al. developed CycLuc1, in which a pyrrolidine moiety is fused to the benzothiazole moiety of DLH2. The wavelength of CycLuc1 is $599 \mathrm{~nm}\left(K_{\mathrm{m}}=0.10\right.$ and $1.06 \mu \mathrm{M}$ in Table 2), which is longer than that of DLH2 due to electron donation from the fused $\mathrm{N}$-hetero ring [75]. The intensity of CycLuc1 BLI in the brain striatum is eight-times more than that of DLH2 [57].

Similarly, Li et al. developed CybLuc, in which the hydroxy group of DLH2 is replaced with an N-cycloalkyl group, shifting the wavelength from that of DLH2 to $603 \mathrm{~nm}$ $\left(K_{\mathrm{m}}=0.16 \mu \mathrm{M}\right.$ in Table 2). The intensity of CybLuc BLI in the brain hippocampus is approximately 18-times higher than that of DLH2 [73]. Furthermore, since the hydrophobicity of these luciferin analogues is higher than that of DLH2, their blood-brain barrier (BBB) permeability is improved, resulting in higher BLI intensity in deep-brain tissues.

In contrast, Iwano et al. developed AkaLumine, in which only the thiazoline moiety of DLH2 is retained. The benzothiazole moiety is substituted with a simple benzene ring, and the $\pi$-conjugation of the molecule is extended with olefins [84]. The wavelength of AkaLumine is $675 \mathrm{~nm}\left(K_{\mathrm{m}}=0.195-2.78 \mu \mathrm{M}\right.$ in Table 2), which shows in the NIR region, and its hydrophobicity is improved, resulting in higher cell-membrane permeability. However, AkaLumine is not soluble in phosphate buffered saline (PBS) or ultra-pure water to the amount needed for administration to animals. This is an example of the trade-off relationship between cell-membrane permeability and solubility for administration. Accordingly, in order to allow better water solubility than that of AkaLumine, the related luciferin analogues TokeOni and seMpai were developed [58,82]. These analogues are discussed in more detail in Section 3.

Moreover, Ikeda et al. synthesized NIRLuc2 based on AkaLumine, with a fused $\mathrm{N}$-hetero ring (like CycLuc1). NIRLuc2 exhibits wavelength at $683 \mathrm{~nm}\left(K_{\mathrm{m}}=1.05 \mu \mathrm{M}\right.$ in Table 2) [83]. However, unlike AkaLumine, NIRLuc2 is soluble in PBS (-) containing 5\% DMSO. The authors then performed BLI, using NIRLuc2 on a subcutaneous tumor mouse model after intraperitoneal administration, revealing that the luminescence intensity of NIRLuc2 is approximately seven-fold that of DLH2 and similar to that of AkaLumine [83].

Extending the $\pi$-conjugation of DLH2 is a valid strategy for obtaining analogues with wavelengths in the NIR region. Using this strategy, Anderson et al. developed infraluciferin (iLH2), in which the $\pi$-conjugation is extended with an olefin moiety [90]. The wavelength of iLH2 upon reaction with a S284T mutant Fluc is $706 \mathrm{~nm}\left(K_{\mathrm{m}}=6.0 \mu \mathrm{M}\right.$ with $\times 5$ Flu mutant in Table 2). The same authors have also developed an in vivo dual-imaging technique that combines iLH2 and DLH2 with two different enzymes, presenting the possibility of observing new biological events by tracking two processes simultaneously [91]. In addition, Hall et al. synthesized $\mathrm{NH}_{2}-\mathrm{NpLH} 2$, in which the $\pi$-conjugation of the benzothiazole moiety in DLH2 is extended by fusion with an aromatic ring at the $6^{\prime}$ - and $7^{\prime}$ - positions [74]. $\mathrm{NH}_{2}-\mathrm{NpLH} 2$ reacts with CBR2opt, which is a mutant luciferase based on click beetle luciferase, to produced light with a wavelength of $743 \mathrm{~nm}\left(K_{\mathrm{m}}=0.5 \mu \mathrm{M}\right.$ in Table 2). BLI of mice, using $\mathrm{NH}_{2}-\mathrm{NpLH} 2 / \mathrm{CBR} 2 \mathrm{opt}$, is not significantly improved compared to those using DLH2/CBR2opt or TokeOni/Luc2. However, since there is no other bioluminescence reaction with a wavelength as long as $743 \mathrm{~nm}$, the application of $\mathrm{NH}_{2}-\mathrm{NpLH} 2$ could be expanded by employing it in combination with an NIR-fluorescent protein for BRET imaging.

\subsection{The Development and Evaluation of Combinations of Luciferin Analogues and Luciferase Mutants}

Zambito et al. investigated the bioluminescence characteristics of each possible combination of luciferin (DLH2, CycLuc1, $\mathrm{NH}_{2}-\mathrm{NpLH} 2$, or TokeOni) and luciferase (Luc2, CBR2, CBG99, or AkaLuc) [93]. The bioluminescence intensities and time-course of each combination were found to be different, indicating that there is an optimal luciferase for each substrate. The highest luminescence intensity for each luciferin, the luciferase used, and the time point at which it was presented were reported to be DLH2/Luc2 at 10 min, CycLuc1/AkaLuc at $10 \mathrm{~min}, \mathrm{NH}_{2}-\mathrm{NpLH} 2 / \mathrm{CBR} 2$ at $20 \mathrm{~min}$, and TokeOni/AkaLuc at 10 or $15 \mathrm{~min}$. Additionally, they measured the bioluminescence wavelength of each combina- 
tion in vivo, using bandpass filters. Interestingly, the wavelength was very different for each combination. That for DLH2/Luc2 was $610 \mathrm{~nm}$, DLH2/CBG99 was $540 \mathrm{~nm}, \mathrm{NH}_{2-}^{-}$ $\mathrm{NpLH} 2 / \mathrm{CBR} 2$ was $730 \mathrm{~nm}$, and $\mathrm{NH}_{2}-\mathrm{NpLH} 2 / \mathrm{CBG} 99$ was $620 \mathrm{~nm}$. Each combination for DLH2 and $\mathrm{NH}_{2}-\mathrm{NpLH} 2$ shifts by approximately $100 \mathrm{~nm}$, depending on the luciferase. Conversely, the wavelength for CycLuc1/AkaLuc was $600 \mathrm{~nm}$, and that for TokeOni/AkaLuc was $660 \mathrm{~nm}$. Although the wavelengths for these two substrates change with different luciferases, the degree of the shift is approximately $20-40 \mathrm{~nm}$. Thus, the combination of luciferin and luciferase is very important, and if the right combination is not used, it will be difficult to detect the observed tissues with high sensitivity.

These results demonstrate that bioluminescence intensity and wavelength can be changed significantly by developing luciferase mutants specialized for luciferin analogues. Furthermore, orthogonal combinations with characteristic properties can be expanded the variation of applications. For instance, Prescher et al. developed orthogonal combinations of luciferin analogues and luciferase mutants [94-96]. They reported that the bioluminescence of PhOH-Luc (Figure 1A) with Fluc is weak. However, it is improved by using a mutant luciferase named G4 in which the amino residues near the active site were restructured, using Rosetta software [97-99]. The resulting PhOH-Luc/G4 pair was found to exhibit better bioluminescence activity than the PhOH-Luc/Fluc pair. Using the same method, they developed three different specialized mutants, such as mut95, mut53, and mut81, that adapts to each of the substrates $7^{\prime}$-DMAMeLuc, 4'-BrLuc, and $4^{\prime}$-MorphoLuc (Figure 1A), respectively [94]. These unique luciferin-luciferase pairs enabled orthogonal triplet and quartet imaging to be readily achieved. In the future, this kind of multiple artificial bioluminescence may enable multicomponent imaging.

A)<smiles>O=C(O)C1CSC(c2ccc(-c3nc4ccc(O)cc4s3)c(O)c2)=N1</smiles><smiles>O=C(O)C1CSC(c2nc3c(Br)cc(O)cc3s2)=N1</smiles>

4'-BrLuc<smiles>CN(C)Cc1c(O)ccc2nc(C3=NC(C(=O)O)CS3)sc12</smiles>

7'-DMAMeLuc<smiles>O=C(O)C1CSC(c2nc3c(CN4CCOCC4)cc(O)cc3s2)=N1</smiles>

4'-MorphoLuc
B)<smiles>CN(C)c1ccc(-c2ccc(C3=NC(C(=O)O)CS3)cc2)cc1</smiles><smiles>C=CCc1c(O)ccc2cc(/C=C/C3=NC(C(=O)O)CS3)ccc12</smiles><smiles>C=CCc1cc(/C=C/C=C/C2=NC(C(=O)O)CS2)ccc1N(C)C</smiles><smiles>C=CCc1c(N(C)C)ccc2cc(/C=C/C3=NC(C(=O)O)CS3)ccc12</smiles>

Figure 1. The structures of several artificial bioluminescence substrates (A) and weak-intensity luciferin analogues (B).

Maki et al. reported a series of luciferin analogues (Figure 1B) that react with Fluc and to produce NIR light [100-103], and several of them were evaluated for BLI, using a mouse model. However, these analogues exhibit much lower luminescence intensities than TokeOni. Nevertheless, if a high-orthogonality pair can be realized by developing a specialized luciferase for analogue, using a software-based mutation methodology similar to that employed by Prescher et al., it may be suitable for successful application in vivo.

Indeed, dual-color BLI technology has already been explored in some animal studies. For instance, Aswendt et al. performed dual-color in vivo BLI of mouse brain tissues, allowing them to monitor both stem cell survival and differentiation in one imaging session simultaneously [104]. Furthermore, Doi et al. monitored the expression profiles of two different genes in Caenorhabditis elegans, using a dual-luciferase system based on Eluc (Emerald luciferase) and SLR (stable luciferase red) [105]. Dual/multi-color BLI system 
enables us to monitor several events, such as several genes' expression and cellular events. Most of the previous research detected a single biological event, using single-color BLI. Thus, multicolor BLI may help to discover complex biological event in the future.

\section{Chemical and Physical Characteristics of the NIR Luciferin Analogues TokeOni and seMpai}

3.1. Development of TokeOni (AkaLumine-HCl)

The solubilities of AkaLumine in PBS and ultra-pure water are very poor, and thus usability was limited for in vivo imaging [58,83]. Therefore, TokeOni [58] and seMpai [82], the hydrochloric acid salt of AkaLumine and $\mathrm{N}$-atom containing AkaLumine derivative, respectively, were prepared with the aim of improving water solubility. The wavelength from TokeOni upon reaction with Fluc occurs at $677 \mathrm{~nm}$, similar to that of AkaLumine $(675 \mathrm{~nm})$ [58]. However, the water solubility of AkaLumine is $2 \mathrm{mM}$ in ultra-pure water, while that of TokeOni is $40 \mathrm{mM}$, which is 20-fold higher [58]. This makes it possible to administer the reagent with a smaller solution volume and a higher concentration than Akalumine. Furthermore, the intensity of BLI in the lung tissue of mice achieved using TokeOni is significantly higher than that achieved with DLH2 and CycLuc1. However, the luminescence intensity of TokeOni/Fluc is not sufficient for imaging in large animal models, such as marmosets.

Accordingly, Iwano et al. developed a mutant luciferase named AkaLuc, which was tailored for TokeOni, and termed their new TokeOni/AkaLuc combination method as AkaBLI [81]. The intensity of AkaBLI (TokeOni/AkaLuc) is approximately 10-fold higher in cells, 52-fold higher in mouse lung, and 1400-fold higher in mouse brain tissue than that obtained with DLH2/Fluc. In addition, AkaBLI was able to detect single mouse lung cell and to quantify 1-10 cells. Moreover, AkaBLI with video-rate was able to monitor signals from the brain striatum in freely moving mice and common marmoset. Although AkaBLI was sufficiently utilized for deep-tissue imaging, this system was not enabled to quantitatively detect signals from exosomes [54]. This result suggests the need for new luciferin analogues that produce sufficient light, even under low-ATP-concentration conditions.

\subsection{Development of seMpai}

Two characteristics of TokeOni were improved by seMpai; since the $\mathrm{pH}$ value of TokeOni is acidic [89], acidosis is a potential problem, and hepatic background signals are detected when using TokeOni $[89,106]$ but not when using DLH2. Furthermore, seMpai is a luciferin analogue designed with containing $\mathrm{N}$-atom in the AkaLumine moiety, slightly changing its bioluminescence reaction with Fluc and AkaLuc $\left(K_{\mathrm{m}}=6.2\right.$ and $44.9 \mu \mathrm{M}$, respectively in Table 2). Moreover, seMpai allows high-sensitivity detection in in vivo BLI, and it can be used to detect pulmonary micro-metastases. In addition, seMpai is highly soluble (69 mM) in PBS (pH 7.4) [82] and does not produce hepatic background signals in breast cancer metastasis models [89]. However, seMpai BLI cannot detect biological events at single-cell-level resolutions, like AkaBLI. Thus, the future development of a novel mutant luciferase specifically for seMpai may realize single-cell-level resolution imaging in vivo. Interestingly, the in vivo dynamics of seMpai are similar to those of DLH2 [86], as described below.

\subsection{Differences between Luciferin Analogue Dynamics In Vivo}

Recent studies have provided important information for the selection of in vivo BLI systems. For instance, Fukuchi et al. performed a comparative analysis of DLH2, TokeOni and seMpai by monitoring the expression of brain-derived neurotrophic factor (BDNF) in Bdnf-luc transgenic mice. They reported the interesting finding that TokeOni BLI shows a different luminescence than those for DLH2 and seMpai, which show the same pattern in brain BLI [86]. Furthermore, TokeOni is more useful than seMpai for brain BLI [81,86], as it exhibits a higher BBB permeability than seMpai, due to its higher hydrophobicity. 
The fact that bioluminescence patterns change depending on the tissue permeability of the luciferin analogues used is a serious problem because it means that the chemical and physical properties of luciferin analogues have significant effects on biological discovery. Nevertheless, since seMpai BLI reduces hepatic background signals, it is very useful for the study of systemic mouse models, such as those used to study metastasis [89] (Figure 2). Thus, it is important that researchers fully understand the characteristics of their chosen in vivo BLI system when applying it to their studies. There are very few reported studies that focus on comparative analysis of the in vivo dynamics and kinetics of luciferin analogues based on their physicochemical properties. Thus, it is necessary that the appropriate luminescence tools be determined according to the organ(s) to be observed.<smiles>CN(C)c1ccc(/C=C/C=C/C2=NC(C(=O)O)CS2)cc1</smiles>

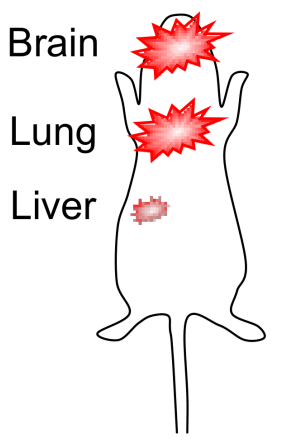

\section{$\checkmark$ High penetration of BBB}

$\checkmark$ Weak hepatic background<smiles>CN(C)c1ccc(/C=C/C=C/C2=NC(C(=O)O)CS2)nc1</smiles>

seMpai

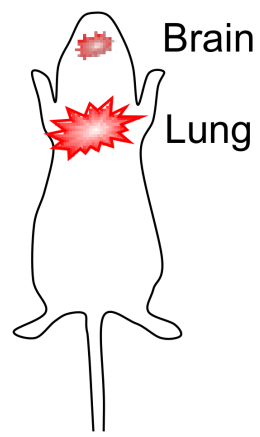

\section{$\checkmark$ Low penetration of BBB}

$\checkmark$ Without hepatic background

Figure 2. The different bioluminescence imaging (BLI) activities of TokeOni and seMpai and their structures. TokeOni enables high-resolution imaging of brain and lung tissues at the single-cell level but presents hepatic background signals, which is caused by its hydrophobicity; however, seMpai enables high-resolution BLI without hepatic background signals, but its hydrophilicity interferes its penetration of the blood-brain barrier (BBB).

\section{Conclusions}

In this review, we have summarized the development and application of luciferin analogues for in vivo BLI and NIR imaging technology. We suggest that the development of luciferin analogues should not just focus on bioluminescence activity, but also consider improved pharmacokinetics for animal safety. The informed combination of luciferin analogue and mutant luciferase can be used to tailor luminescence wavelength and intensity, as well as dynamics in vivo. Thus, researchers using such techniques for life science and medical research must be aware of the influence of BLI system selection.

Author Contributions: Writing—original draft preparation, R.S.-M.; writing—review and editing, R.S.-M., J.N., G.K., N.K., R.O., S.A.M., and H.A.; funding acquisition, R.S.-M. All authors have read and agreed to the published version of the manuscript.

Funding: This study was supported by JSPS KAKENHI (Grant No. JP20K22724; Grant-in-Aid for Research Activity Start-up to R.S.-M.).

Acknowledgments: We thank the members of Maki's and Aoyama's laboratory, and Kurogane Kasei Co., Ltd., for meaningful discussion and support. 
Conflicts of Interest: The authors declare no conflict of interest.

$\begin{array}{ll}\text { Abbreviations } \\ \text { ATP } & \text { Adenosine triphosphate } \\ \text { BBB } & \text { Blood-brain barrier } \\ \text { BDNF } & \text { Brain-derived neurotrophic factor } \\ \text { BLI } & \text { Bioluminescence imaging } \\ \text { CBR } & \text { Click beetle luciferase } \\ \text { CTZ } & \text { Coelenterazine } \\ \text { DLH2 } & \text { D-Luciferin } \\ \text { Eluc } & \text { Emerald luciferase } \\ \text { Fluc } & \text { Firefly luciferase } \\ \text { FMZ } & \text { Furimazine } \\ \text { FMZ } & \text { Furimazine } \\ \text { Gluc } & \text { Gaussia luciferase } \\ \text { iLH2 } & \text { Infraluciferin } \\ \text { NIR } & \text { Near-infrared } \\ \text { Oluc } & \text { Oplophorus luciferase } \\ \text { PBS } & \text { Phosphate buffered saline } \\ \text { Rluc } & \text { Renilla luciferase } \\ \text { SLR } & \text { Stable luciferase red }\end{array}$

\section{References}

1. Wilson, T.; Hastings, J.W. Bioluminescence. Annu. Rev. Cell Dev. Biol. 1998, 14, 197-230. [CrossRef]

2. Shimomura, O. The Fireflies and Luminous Insects. In Bioluminescence; World Scientific: Toh Tuck Link, Singapore, $2012 ;$ pp. 1-30. ISBN 978-981-4366-08-3. [CrossRef]

3. Kaskova, Z.M.; Tsarkova, A.S.; Yampolsky, I.V. 1001 lights: Luciferins, luciferases, their mechanisms of action and applications in chemical analysis, biology and medicine. Chem. Soc. Rev. 2016, 45, 6048-6077. [CrossRef]

4. Fraga, H. Firefly luminescence: A historical perspective and recent developments. Photochem. Photobiol. Sci. 2008, 7, 146-158. [CrossRef] [PubMed]

5. Branchini, B.R.; Murtiashaw, M.H.; Magyar, R.A.; Portier, N.C.; Ruggiero, M.C.; Stroh, J.G. Yellow-green and red firefly bioluminescence from 5,5-dimethyloxyluciferin. J. Am. Chem. Soc. 2002, 124, 2112-2113. [CrossRef] [PubMed]

6. Branchini, B.R.; Southworth, T.L.; Murtiashaw, M.H.; Magyar, R.A.; Gonzalez, S.A.; Ruggiero, M.C.; Stroh, J.G. An alternative mechanism of bioluminescence color determination in firefly luciferase. Biochemistry 2004, 43, 7255-7262. [CrossRef] [PubMed]

7. Hirano, T.; Hasumi, Y.; Ohtsuka, K.; Maki, S.; Niwa, H.; Yamaji, M.; Hashizume, D. Spectroscopic studies of the light-color modulation mechanism of firefly (Beetle) bioluminescence. J. Am. Chem. Soc. 2009, 131, 2385-2396. [CrossRef]

8. Shimomura, O.; Masugi, T.; Johnson, F.H.; Haneda, Y. Properties and reaction mechanism of the bioluminescence system of the deep-sea shrimp Oplophorus gracilorostris. Biochemistry 1978, 17, 994-998. [CrossRef]

9. Inouye, S.; Watanabe, K.; Nakamura, H.; Shimomura, O. Secretional luciferase of the luminous shrimp Oplophorus gracilirostris: cDNA cloning of a novel imidazopyrazinone luciferase. FEBS Lett. 2000, 481, 19-25. [CrossRef]

10. Krasitskaya, V.V.; Bashmakova, E.E.; Frank, L.A. Coelenterazine-Dependent Luciferases as a Powerful Analytical Tool for Research and Biomedical Applications. Int. J. Mol. Sci. 2020, 21, 7465. [CrossRef]

11. Oba, Y.; Konishi, K.; Yano, D.; Shibata, H.; Kato, D.; Shirai, T. Resurrecting the ancient glow of the fireflies. Sci. Adv. 2020, 6, eabc5705. [CrossRef]

12. Thornton, J.W. Resurrecting ancient genes: Experimental analysis of extinct molecules. Nat. Rev. Genet. 2004, 5, 366-375. [CrossRef]

13. Thorne, N.; Inglese, J.; Auld, D.S. Illuminating insights into firefly luciferase and other bioluminescent reporters used in chemical biology. Chem. Biol. 2010, 17, 646-657. [CrossRef]

14. Badr, C.E.; Tannous, B.A. Bioluminescence imaging: Progress and applications. Trends Biotechnol. 2011, 29, 624-633. [CrossRef]

15. Krishnasamy, S.; Weng, Y.-C.; Thammisetty, S.S.; Phaneuf, D.; Lalancette-Hebert, M.; Kriz, J. Molecular imaging of nestin in neuroinflammatory conditions reveals marked signal induction in activated microglia. J. Neuroinflammation 2017, 14, 45. [CrossRef] [PubMed]

16. Dorsaz, S.; Coste, A.T.; Sanglard, D. Red-shifted firefly luciferase optimized for Candida albicans in vivo bioluminescence imaging. Front. Microbiol. 2017, 8, 1478. [CrossRef] [PubMed]

17. Tannert, A.; Ramoji, A.; Neugebauer, U.; Popp, J. Photonic monitoring of treatment during infection and sepsis: Development of new detection strategies and potential clinical applications. Anal. Bioanal. Chem. 2018, 410, 773-790. [CrossRef] [PubMed] 
18. Lalancette-Hébert, M.; Faustino, J.; Thammisetty, S.S.; Chip, S.; Vexler, Z.S.; Kriz, J. Live imaging of the innate immune response in neonates reveals differential TLR2 dependent activation patterns in sterile inflammation and infection. Brain. Behav. Immun. 2017, 65, 312-327. [CrossRef] [PubMed]

19. Rahimian, R.; Cordeau, P.; Kriz, J. Brain response to injuries: When microglia go sexist. Neuroscience 2019, 405, 14-23. [CrossRef]

20. Cordeau, P.; Kriz, J. Real-Time Imaging after Cerebral Ischemia. In Methods in Enzymology; Elsevier Inc.: Amsterdam, The Netherlands, 2012; Volume 506, pp. 117-133. ISBN 9780123918567. [CrossRef]

21. Barash, N.R.; Nosala, C.; Pham, J.K.; McInally, S.G.; Gourguechon, S.; McCarthy-Sinclair, B.; Dawson, S.C. Giardia colonizes and encysts in high-density foci in the murine small intestine. mSphere 2017, 2, 1-20. [CrossRef]

22. Martin, R.M.; Fowler, J.L.; Cromer, M.K.; Lesch, B.J.; Ponce, E.; Uchida, N.; Nishimura, T.; Porteus, M.H.; Loh, K.M. Improving the safety of human pluripotent stem cell therapies using genome-edited orthogonal safeguards. Nat. Commun. 2020, 11, 2713. [CrossRef] [PubMed]

23. Furuya, T.; Takehara, I.; Shimura, A.; Kishimoto, H.; Yasujima, T.; Ohta, K.; Shirasaka, Y.; Yuasa, H.; Inoue, K. Organic anion transporter 1 (OAT1/SLC22A6) enhances bioluminescence based on D-luciferin-luciferase reaction in living cells by facilitating the intracellular accumulation of d-luciferin. Biochem. Biophys. Res. Commun. 2018, 495, 2152-2157. [CrossRef]

24. Yamada, K.; Noguchi, K.; Kimitsuki, K.; Kaimori, R.; Saito, N.; Komeno, T.; Nakajima, N.; Furuta, Y.; Nishizono, A. Reevaluation of the efficacy of favipiravir against rabies virus using in vivo imaging analysis. Antiviral Res. 2019, 172, 104641. [CrossRef] [PubMed]

25. Mehle, A. Fiat luc: Bioluminescence imaging reveals in vivo viral replication dynamics. PLoS Pathog. 2015, 11, 1-7. [CrossRef] [PubMed]

26. Cook, S.H.; Griffin, D.E. Luciferase imaging of a neurotropic viral infection in intact animals. J. Virol. 2003, 77, 5333-5338. [CrossRef] [PubMed]

27. Smale, S.T. Luciferase Assay. Cold Spring Harb. Protoc. 2010, 2010, pdb.prot5421. [CrossRef]

28. Bennett, J.; Duan, D.; Engelhardt, J.F.; Maguire, A.M. Real-time, noninvasive in vivo assessment of adeno-associated virusmediated retinal transduction. Investig. Ophthalmol. Vis. Sci. 1997, 38, 2857-2863.

29. Contag, P.R.; Nick Olomu, I.; Stevenson, D.K.; Contag, C.H. Bioluminescent indicators in living mammals. Nat. Med. 1998, 4 , 245-247. [CrossRef]

30. Fleiss, A.; Sarkisyan, K.S. A brief review of bioluminescent systems (2019). Curr. Genet. 2019, 65, 877-882. [CrossRef]

31. Chen, L.; Chen, Z.; Zheng, S.; Fan, L.; Zhu, L.; Yu, J.; Tang, C.; Liu, Q.; Xiong, Y. Study on mechanism of elemene reversing tumor multidrug resistance based on luminescence pharmacokinetics in tumor cellsin vitroandin vivo. RSC Adv. 2020, 10, 34928-34937. [CrossRef]

32. Alsawaftah, N.; Farooq, A.; Dhou, S.; Majdalawieh, A.F. Bioluminescence imaging applications in cancer: A comprehensive review. IEEE Rev. Biomed. Eng. 2021, 14, 307-326. [CrossRef]

33. Nakayama, J.; Ito, E.; Fujimoto, J.; Watanabe, S.; Semba, K. Comparative analysis of gene regulatory networks of highly metastatic breast cancer cells established by orthotopic transplantation and intra-circulation injection. Int. J. Oncol. 2017, 50, 497-504. [CrossRef] [PubMed]

34. Kuchimaru, T.; Kataoka, N.; Nakagawa, K.; Isozaki, T.; Miyabara, H.; Minegishi, M.; Kadonosono, T.; Kizaka-Kondoh, S. A reliable murine model of bone metastasis by injecting cancer cells through caudal arteries. Nat. Commun. 2018, 9, 2981. [CrossRef]

35. Kuroiwa, Y.; Nakayama, J.; Adachi, C.; Inoue, T.; Watanabe, S.; Semba, K. Proliferative classification of intracranially injected HER2-positive breast cancer cell lines. Cancers 2020, 12, 1811. [CrossRef]

36. Han, Y.; Nakayama, J.; Hayashi, Y.; Jeong, S.; Futakuchi, M.; Ito, E.; Watanabe, S.; Semba, K. Establishment and characterization of highly osteolytic luminal breast cancer cell lines by intracaudal arterial injection. Genes Cells 2020, 25, 111-123. [CrossRef]

37. Yanagihara, K.; Takigahira, M.; Takeshita, F.; Komatsu, T.; Nishio, K.; Hasegawa, F.; Ochiya, T. A photon counting technique for quantitatively evaluating progression of peritoneal tumor dissemination. Cancer Res. 2006, 66, 7532-7539. [CrossRef] [PubMed]

38. Manni, I.; de Latouliere, L.; Gurtner, A.; Piaggio, G. Transgenic animal models to visualize cancer-related cellular processes by bioluminescence imaging. Front. Pharmacol. 2019, 10, 235. [CrossRef]

39. Kim, J.-B.; Urban, K.; Cochran, E.; Lee, S.; Ang, A.; Rice, B.; Bata, A.; Campbell, K.; Coffee, R.; Gorodinsky, A.; et al. Non-invasive detection of a small number of bioluminescent cancer cells in vivo. PLoS ONE 2010, 5, e9364. [CrossRef] [PubMed]

40. Mizui, Y.; Eguchi, M.; Tanaka, M.; Ikeda, Y.; Yoshimura, H.; Ozawa, T.; Citterio, D.; Hiruta, Y. Long-term single cell bioluminescence imaging with C-3 position protected coelenterazine analogues. Org. Biomol. Chem. 2021, 19, 579-586. [CrossRef]

41. Nishihara, R.; Hoshino, E.; Kakudate, Y.; Kishigami, S.; Iwasawa, N.; Sasaki, S.; Nakajima, T.; Sato, M.; Nishiyama, S.; Citterio, D.; et al. Azide- and dye-conjugated coelenterazine analogues for a multiplex molecular imaging platform. Bioconjug. Chem. 2018, 29, 1922-1931. [CrossRef]

42. Nishihara, R.; Suzuki, H.; Hoshino, E.; Suganuma, S.; Sato, M.; Saitoh, T.; Nishiyama, S.; Iwasawa, N.; Citterio, D.; Suzuki, K. Bioluminescent coelenterazine derivatives with imidazopyrazinone C-6 extended substitution. Chem. Commun. 2015, 51, 391-394. [CrossRef]

43. Nishihara, R.; Paulmurugan, R.; Nakajima, T.; Yamamoto, E.; Natarajan, A.; Afjei, R.; Hiruta, Y.; Iwasawa, N.; Nishiyama, S.; Citterio, D.; et al. Highly bright and stable NIR-BRET with blue-shifted coelenterazine derivatives for deep-tissue imaging of molecular events in vivo. Theranostics 2019, 9, 2646-2661. [CrossRef] [PubMed] 
44. Coutant, E.P.; Gagnot, G.; Hervin, V.; Baatallah, R.; Goyard, S.; Jacob, Y.; Rose, T.; Janin, Y.L. Bioluminescence profiling of NanoKAZ/NanoLuc luciferase using a chemical library of coelenterazine analogues. Chem. A Eur. J. 2020, 26, 948-958. [CrossRef] [PubMed]

45. Belarbi, E.; Legros, V.; Basset, J.; Desprès, P.; Roques, P.; Choumet, V. Bioluminescent ross river rvrus allows live monitoring of acute and long-term alphaviral infection by in vivo imaging. Viruses 2019, 11, 584. [CrossRef] [PubMed]

46. Gupta, D.; Liang, X.; Pavlova, S.; Wiklander, O.P.B.; Corso, G.; Zhao, Y.; Saher, O.; Bost, J.; Zickler, A.M.; Piffko, A.; et al. Quantification of extracellular vesicles in vitro and in vivo using sensitive bioluminescence imaging. J. Extracell. Vesicles 2020, 9, 1800222. [CrossRef]

47. Inagaki, S.; Agetsuma, M.; Ohara, S.; Iijima, T.; Yokota, H.; Wazawa, T.; Arai, Y.; Nagai, T. Imaging local brain activity of multiple freely moving mice sharing the same environment. Sci. Rep. 2019, 9, 7460. [CrossRef]

48. Anindita, P.D.; Sasaki, M.; Nobori, H.; Sato, A.; Carr, M.; Ito, N.; Sugiyama, M.; Orba, Y.; Sawa, H. Generation of recombinant rabies viruses encoding NanoLuc luciferase for antiviral activity assays. Virus Res. 2016, 215, 121-128. [CrossRef]

49. Hall, M.P.; Unch, J.; Binkowski, B.F.; Valley, M.P.; Butler, B.L.; Wood, M.G.; Otto, P.; Zimmerman, K.; Vidugiris, G.; Machleidt, T.; et al. Engineered luciferase reporter from a deep sea shrimp utilizing a novel imidazopyrazinone substrate. ACS Chem. Biol. 2012, 7, 1848-1857. [CrossRef]

50. Stacer, A.C.; Nyati, S.; Moudgil, P.; Iyengar, R.; Luker, K.E.; Rehemtulla, A.; Luker, G.D. NanoLuc reporter for dual luciferase imaging in living animals. Mol. Imaging 2013, 12, 457-469. [CrossRef]

51. Dixon, A.S.; Schwinn, M.K.; Hall, M.P.; Zimmerman, K.; Otto, P.; Lubben, T.H.; Butler, B.L.; Binkowski, B.F.; Machleidt, T.; Kirkland, T.A.; et al. NanoLuc complementation reporter optimized for accurate measurement of protein interactions in cells. ACS Chem. Biol. 2016, 11, 400-408. [CrossRef]

52. Yeh, H.W.; Xiong, Y.; Wu, T.; Chen, M.; Ji, A.; Li, X.; Ai, H.W. ATP-independent bioluminescent reporter variants to improve in vivo imaging. ACS Chem. Biol. 2019, 14, 959-965. [CrossRef] [PubMed]

53. Yeh, H.W.; Wu, T.; Chen, M.; Ai, H.W. Identification of factors complicating bioluminescence imaging. Biochemistry 2019, 58, 1689-1697. [CrossRef] [PubMed]

54. Hikita, T.; Miyata, M.; Watanabe, R.; Oneyama, C. In vivo imaging of long-term accumulation of cancer-derived exosomes using a BRET-based reporter. Sci. Rep. 2020, 10, 16616. [CrossRef]

55. Jiang, T.; Du, L.; Li, M. Lighting up bioluminescence with coelenterazine: Strategies and applications. Photochem. Photobiol. Sci. 2016, 15, 466-480. [CrossRef]

56. Love, A.C.; Prescher, J.A. Seeing (and using) the light: Recent developments in bioluminescence technology. Cell Chem. Biol. 2020, 27, 904-920. [CrossRef]

57. Evans, M.S.; Chaurette, J.P.; Adams, S.T.; Reddy, G.R.; Paley, M.A.; Aronin, N.; Prescher, J.A.; Miller, S.C. A synthetic luciferin improves bioluminescence imaging in live mice. Nat. Methods 2014, 11, 393-395. [CrossRef] [PubMed]

58. Kuchimaru, T.; Iwano, S.; Kiyama, M.; Mitsumata, S.; Kadonosono, T.; Niwa, H.; Maki, S.; Kizaka-Kondoh, S. A luciferin analogue generating near-infrared bioluminescence achieves highly sensitive deep-tissue imaging. Nat. Commun. 2016, 7, 11856. [CrossRef]

59. Weissleder, R. A clearer vision for in vivo imaging. Nat. Biotechnol. 2001, 19, 316-317. [CrossRef] [PubMed]

60. Dawson, J.B.; Barker, D.J.; Ellis, D.J.; Cotterill, J.A.; Grassam, E.; Fisher, G.W.; Feather, J.W. A theoretical and experimental study of light absorption and scattering by in vivo skin. Phys. Med. Biol. 1980, 25, 695-709. [CrossRef]

61. Lee, K.-H.; Byun, S.S.; Paik, J.-Y.; Lee, S.Y.; Song, S.H.; Choe, Y.S.; Kim, B.-T. Cell uptake and tissue distribution of radioiodine labelled D-luciferin: Implications for luciferase-based gene imaging. Nucl. Med. Commun. 2003, 24, 1003-1009. [CrossRef]

62. Berger, F.; Paulmurugan, R.; Bhaumik, S.; Gambhir, S.S. Uptake kinetics and biodistribution of ${ }^{14}$ C-D-luciferin-A radiolabeled substrate for the firefly luciferase catalyzed bioluminescence reaction: Impact on bioluminescence-based reporter gene imaging. Eur. J. Nucl. Med. Mol. Imaging 2008, 35, 2275-2285. [CrossRef]

63. Miller, S.C.; Mofford, D.M.; Adams, S.T. Lessons learned from luminous luciferins and latent luciferases. ACS Chem. Biol. 2018, 13, 1734-1740. [CrossRef] [PubMed]

64. Li, S.; Ruan, Z.; Zhang, H.; Xu, H. Recent achievements of bioluminescence imaging based on firefly luciferin-luciferase system. Eur. J. Med. Chem. 2021, 211, 113111. [CrossRef] [PubMed]

65. Kajiyama, N.; Nakano, E. Isolation and characterization of mutants of firefly luciferase which produce different colors of light. Protein Eng. 1991, 4, 691-693. [CrossRef]

66. Branchini, B.R.; Magyar, R.A.; Murtiashaw, M.H.; Anderson, S.M.; Helgerson, L.C.; Zimmer, M. Site-directed mutagenesis of firefly luciferase active site amino acids: A proposed model for bioluminescence color. Biochemistry 1999, 38, 13223-13230. [CrossRef] [PubMed]

67. Nakajima, Y.; Kimura, T.; Sugata, K.; Enomoto, T.; Asakawa, A.; Kubota, H.; Ikeda, M.; Ohmiya, Y. Multicolor luciferase assay system: One-step monitoring of multiple gene expressions with a single substrate. Biotechniques 2005, 38, 891-894. [CrossRef] [PubMed]

68. Viviani, V.R.; Bevilaqua, V.R.; de Souza, D.R.; Pelentir, G.F.; Kakiuchi, M.; Hirano, T. A very bright far-red bioluminescence emitting combination based on engineered railroad worm luciferase and $6^{\prime}$-amino-analogs for bioimaging purposes. Int. J. Mol. Sci. 2020, 22, 303. [CrossRef] [PubMed]

69. Branchini, B.R.; Ablamsky, D.M.; Rosenberg, J.C. Chemically modified firefly luciferase is an efficient source of near-infrared light. Bioconjug. Chem. 2010, 21, 2023-2030. [CrossRef] 
70. Kojima, R.; Takakura, H.; Ozawa, T.; Tada, Y.; Nagano, T.; Urano, Y. Rational design and development of near-infrared-emitting firefly luciferins available in vivo. Angew. Chemie Int. Ed. 2013, 52, 1175-1179. [CrossRef]

71. Mikitsh, J.L.; Chacko, A.M. Pathways for small molecule delivery to the central nervous system across the blood-brain barrier. Perspect. Medicin. Chem. 2014, 11-24. [CrossRef]

72. Harwood, K.R.; Mofford, D.M.; Reddy, G.R.; Miller, S.C. Identification of mutant firefly luciferases that efficiently utilize aminoluciferins. Chem. Biol. 2011, 18, 1649-1657. [CrossRef]

73. Wu, W.; Su, J.; Tang, C.; Bai, H.; Ma, Z.; Zhang, T.; Yuan, Z.; Li, Z.; Zhou, W.; Zhang, H.; et al. CybLuc: An effective aminoluciferin derivative for deep bioluminescence imaging. Anal. Chem. 2017, 89, 4808-4816. [CrossRef]

74. Hall, M.P.; Woodroofe, C.C.; Wood, M.G.; Que, I.; van't Root, M.; Ridwan, Y.; Shi, C.; Kirkland, T.A.; Encell, L.P.; Wood, K.V.; et al Click beetle luciferase mutant and near infrared naphthyl-luciferins for improved bioluminescence imaging. Nat. Commun. 2018, 9, 132. [CrossRef]

75. Reddy, G.R.; Thompson, W.C.; Miller, S.C. Robust light emission from cyclic alkylaminoluciferin substrates for firefly luciferase. J. Am. Chem. Soc. 2010, 132, 13586-13587. [CrossRef] [PubMed]

76. Simonyan, H.; Hurr, C.; Young, C.N. A synthetic luciferin improves in vivo bioluminescence imaging of gene expression in cardiovascular brain regions. Physiol. Genomics 2016, 48, 762-770. [CrossRef]

77. Ji, X.; Adams, S.T.; Miller, S.C. Bioluminescence Imaging in Mice with Synthetic Luciferin Analogues. In Methods in Enzymology; Elsevier Inc.: Amsterdam, The Netherlands, 2020; Volume 640, pp. 165-183. ISBN 9780128211533. [CrossRef]

78. Kleinovink, J.W.; Mezzanotte, L.; Zambito, G.; Fransen, M.F.; Cruz, L.J.; Verbeek, J.S.; Chan, A.; Ossendorp, F.; Löwik, C. A dual-color bioluminescence reporter mouse for simultaneous in vivo imaging of $\mathrm{T}$ cell localization and function. Front. Immunol. 2019, 10, 1-11. [CrossRef] [PubMed]

79. Mezzanotte, L.; Iljas, J.D.; Que, I.; Chan, A.; Kaijzel, E.; Hoeben, R.; Löwik, C. Optimized longitudinal monitoring of stem cell grafts in mouse brain using a novel bioluminescent/near infrared fluorescent fusion reporter. Cell Transplant. 2017, 26, 1878-1889. [CrossRef] [PubMed]

80. Adams, S.T.; Mofford, D.M.; Reddy, G.S.K.K.; Miller, S.C. Firefly luciferase mutants allow substrate-selective bioluminescence imaging in the mouse brain. Angew. Chemie Int. Ed. 2016, 55, 4943-4946. [CrossRef] [PubMed]

81. Iwano, S.; Sugiyama, M.; Hama, H.; Watakabe, A.; Hasegawa, N.; Kuchimaru, T.; Tanaka, K.Z.; Takahashi, M.; Ishida, Y.; Hata, J.; et al. Single-cell bioluminescence imaging of deep tissue in freely moving animals. Science 2018, 359, 935-939. [CrossRef]

82. Saito, R.; Kuchimaru, T.; Higashi, S.; Lu, S.W.; Kiyama, M.; Iwano, S.; Obata, R.; Hirano, T.; Kizaka-Kondoh, S.; Maki, S.A. Synthesis and luminescence properties of near-infrared N-heterocyclic luciferin analogues for in vivo optical imaging. Bull. Chem. Soc. Jpn. 2019, 92, 608-618. [CrossRef]

83. Ikeda, Y.; Nomoto, T.; Hiruta, Y.; Nishiyama, N.; Citterio, D. Ring-fused firefly luciferins: Expanded palette of near-infrared emitting bioluminescent substrates. Anal. Chem. 2020, 92, 4235-4243. [CrossRef]

84. Iwano, S.; Obata, R.; Miura, C.; Kiyama, M.; Hama, K.; Nakamura, M.; Amano, Y.; Kojima, S.; Hirano, T.; Maki, S.; et al Development of simple firefly luciferin analogs emitting blue, green, red, and near-infrared biological window light. Tetrahedron 2013, 69, 3847-3856. [CrossRef]

85. Fukuchi, M.; Izumi, H.; Mori, H.; Kiyama, M.; Otsuka, S.; Maki, S.; Maehata, Y.; Tabuchi, A.; Tsuda, M. Visualizing changes in brain-derived neurotrophic factor (BDNF) expression using bioluminescence imaging in living mice. Sci. Rep. 2017, 7, 4949. [CrossRef] [PubMed]

86. Fukuchi, M.; Saito, R.; Maki, S.; Hagiwara, N.; Nakajima, Y.; Mitazaki, S.; Izumi, H.; Mori, H. Visualization of activity-regulated BDNF expression in the living mouse brain using non-invasive near-infrared bioluminescence imaging. Mol. Brain 2020, 13, 122. [CrossRef] [PubMed]

87. Zhong, C.; Kayamori, K.; Koide, S.; Shinoda, D.; Oshima, M.; Nakajima-Takagi, Y.; Nagai, Y.; Mimura, N.; Sakaida, E.; Yamazaki, S.; et al. Efficacy of the novel tubulin polymerization inhibitor PTC-028 for myelodysplastic syndrome. Cancer Sci. 2020, $4336-4347$. [CrossRef] [PubMed]

88. Raikwar, S.P.; Thangavel, R.; Ahmed, M.E.; Selvakumar, G.P.; Kempuraj, D.; Wu, K.; Khan, O.; Bazley, K.; Bussinger, B.; Kukulka, K.; et al. Real-time noninvasive bioluminescence, ultrasound and photoacoustic imaging in NFKB-RE-Luc transgenic mice reveal glia maturation factor-mediated immediate and sustained spatio-temporal activation of NFKB signaling post-traumatic brain injury in a gender-. Cell. Mol. Neurobiol. 2020. [CrossRef] [PubMed]

89. Nakayama, J.; Saito, R.; Hayashi, Y.; Kitada, N.; Tamaki, S.; Han, Y.; Semba, K.; Maki, S.A. High sensitivity in vivo imaging of cancer metastasis using a near-infrared luciferin analogue seMpai. Int. J. Mol. Sci. 2020, 21, 7896. [CrossRef] [PubMed]

90. Jathoul, A.P.; Grounds, H.; Anderson, J.C.; Pule, M.A. A dual-color far-red to near-infrared firefly luciferin analogue designed for multiparametric bioluminescence imaging. Angew. Chemie Int. Ed. 2014, 53, 13059-13063. [CrossRef]

91. Stowe, C.L.; Burley, T.A.; Allan, H.; Vinci, M.; Kramer-Marek, G.; Ciobota, D.M.; Parkinson, G.N.; Southworth, T.L.; Agliardi, G.; Hotblack, A.; et al. Near-infrared dual bioluminescence imaging in mouse models of cancer using infraluciferin. Elife 2019, 8, 1-22. [CrossRef]

92. Zhang, C.; Yuan, M.; Han, G.; Gao, Y.; Tang, C.; Li, X.; Du, L.; Li, M. Novel caged luciferin derivatives can prolong bioluminescence imaging: In vitro and in vivo. RSC Adv. 2018, 8, 19596-19599. [CrossRef] 
93. Zambito, G.; Gaspar, N.; Ridwan, Y.; Hall, M.P.; Shi, C.; Kirkland, T.A.; Encell, L.P.; Löwik, C.; Mezzanotte, L. Evaluating brightness and spectral properties of click beetle and firefly luciferases using luciferin analogues: Identification of preferred pairings of luciferase and substrate for in vivo bioluminescence imaging. Mol. Imaging Biol. 2020, 22, 1523-1531. [CrossRef]

94. Yao, Z.; Zhang, B.S.; Steinhardt, R.C.; Mills, J.H.; Prescher, J.A. Multicomponent bioluminescence imaging with a $\pi$-extended luciferin. J. Am. Chem. Soc. 2020, 142, 14080-14089. [CrossRef] [PubMed]

95. Jones, K.A.; Porterfield, W.B.; Rathbun, C.M.; McCutcheon, D.C.; Paley, M.A.; Prescher, J.A. Orthogonal luciferase-luciferin pairs for bioluminescence imaging. J. Am. Chem. Soc. 2017, 139, 2351-2358. [CrossRef] [PubMed]

96. Rathbun, C.M.; Porterfield, W.B.; Jones, K.A.; Sagoe, M.J.; Reyes, M.R.; Hua, C.T.; Prescher, J.A. Parallel screening for rapid identification of orthogonal bioluminescent tools. ACS Cent. Sci. 2017, 3, 1254-1261. [CrossRef] [PubMed]

97. Wang, J.; Liu, Y.; Liu, Y.; Zheng, S.; Wang, X.; Zhao, J.; Yang, F.; Zhang, G.; Wang, C.; Chen, P.R. Time-resolved protein activation by proximal decaging in living systems. Nature 2019, 569, 509-513. [CrossRef]

98. Chen, Z.; Boyken, S.E.; Jia, M.; Busch, F.; Flores-Solis, D.; Bick, M.J.; Lu, P.; VanAernum, Z.L.; Sahasrabuddhe, A.; Langan, R.A.; et al. Programmable design of orthogonal protein heterodimers. Nature 2019, 565, 106-111. [CrossRef]

99. Dou, J.; Vorobieva, A.A.; Sheffler, W.; Doyle, L.A.; Park, H.; Bick, M.J.; Mao, B.; Foight, G.W.; Lee, M.Y.; Gagnon, L.A.; et al. De novo design of a fluorescence-activating $\beta$-barrel. Nature 2018, 561, 485-491. [CrossRef] [PubMed]

100. Miura, C.; Kiyama, M.; Iwano, S.; Ito, K.; Obata, R.; Hirano, T.; Maki, S.; Niwa, H. Synthesis and luminescence properties of biphenyl-type firefly luciferin analogs with a new, near-infrared light-emitting bioluminophore. Tetrahedron 2013, 69, 9726-9734. [CrossRef]

101. Kiyama, M.; Iwano, S.; Otsuka, S.; Lu, S.W.; Obata, R.; Miyawaki, A.; Hirano, T.; Maki, S.A. Quantum yield improvement of red-light-emitting firefly luciferin analogues for in vivo bioluminescence imaging. Tetrahedron 2018, 74, 652-660. [CrossRef]

102. Kitada, N.; Saitoh, T.; Ikeda, Y.; Iwano, S.; Obata, R.; Niwa, H.; Hirano, T.; Miyawaki, A.; Suzuki, K.; Nishiyama, S.; et al. Toward bioluminescence in the near-infrared region: Tuning the emission wavelength of firefly luciferin analogues by allyl substitution. Tetrahedron Lett. 2018, 59, 1087-1090. [CrossRef]

103. Kitada, N.; Saito, R.; Obata, R.; Iwano, S.; Karube, K.; Miyawaki, A.; Hirano, T.; Maki, S.A. Development of near-infrared firefly luciferin analogue reacted with wild-type and mutant luciferases. Chirality 2020, 32, 922-931. [CrossRef]

104. Aswendt, M.; Vogel, S.; Schäfer, C.; Jathoul, A.; Pule, M.; Hoehn, M. Quantitative in vivo dual-color bioluminescence imaging in the mouse brain. Neurophotonics 2019, 6, 025006. [CrossRef] [PubMed]

105. Doi, M.; Sato, M.; Ohmiya, Y. In vivo simultaneous analysis of gene expression by dual-color luciferases in caenorhabditis elegans. Int. J. Mol. Sci. 2020, 22, 119. [CrossRef] [PubMed]

106. Su, Y.; Walker, J.R.; Park, Y.; Smith, T.P.; Liu, L.X.; Hall, M.P.; Labanieh, L.; Hurst, R.; Wang, D.C.; Encell, L.P.; et al. Novel NanoLuc substrates enable bright two-population bioluminescence imaging in animals. Nat. Methods 2020, 17, 852-860. [CrossRef] [PubMed] 